\section{Travels of Hochstetter and Haast in New Zealand 1858-1860}

\section{By Mike Johnston and Sascha Nolden}

Nikau Press, Nelson, NZ, 2011. 336 pp.

The two subjects of this book laid the first firm foundations for understanding the geology of New Zealand (NZ), following their work there from 1858 to 1860 . Ferdinand Hochstetter was the geologist (seconded from the Austrian Survey) on board the Austrian vessel Novara, which was undertaking a round-the-world scientific expedition. He found much of interest in NZ, which until his arrival in 1858 had had no professional geologists working there for any length of time; and with the discovery of coal near Auckland, the NZ Government was eager to obtain the services of a trained geologist to give advice on the prospects for coal mining. Gold had already been discovered and on this matter too the Government wanted professional advice. As a result, Hochstetter was granted leave of absence from the Novara and stayed in NZ for nine months, conducting reconnaissance survey work around Auckland, near the coal deposits at Drury on the west coast of the North Island, in the thermal regions of that island, and on the gold deposits of the Coromandel Peninsula to the east of Auckland. Following the success of this work, the authorities of the Province of Nelson in the north of the South Island invited him to survey that part of the country too, where there were known coal deposits and gold, and claims about copper deposits that needed to be adjudicated.

When in Auckland, a German visitor to the country, Julius Haast, met up with Hochstetter and accompanied him on his travels. There is some 'lack of clarity' about Haast's early life in Germany but he had a wife and a son in Europe. Although he had apparently had some education in geology or mineralogy, he was in $\mathrm{NZ}$ with the intention of facilitating German migration to the country. In the event, it was Haast himself who migrated, eventually becoming Geologist to Canterbury Province, founder of the Canterbury Museum, and professor at the new university college in Christchurch. He also started a new family in NZ. His highly successful career as a geologist followed after his short 'apprenticeship' with Hochstetter, with Haast extending the Nelson fieldwork after his new friend departed for Europe, never to return. It was Haast's work in Nelson that led to his subsequent 'gainful employment' in Christchurch. In later years, both friends were rewarded with knighthoods in Austria and NZ respectively and Hochstetter gained a professorship in Vienna.

What Hochstetter and Haast accomplished in a few short months in NZ was truly remarkable. They made topographic and geologic maps; investigated the mineral potentials of the areas they visited; studied kiwis, moas and Maori customs (such as tattooing), and made biological as well as geological observations; and their collections of rocks, minerals, and fossils were subsequently described by specialists in Europe. Unassisted by Hochstetter, Haast also undertook arduous exploration and survey work in wintry conditions in the mountainous, wet, and thickly forested country of Nelson Province and the West Coast.

Haast's story has been told in a mammoth biography by his son H. F. von Haast (1948). Hochstetter's life and work have been written up in Austria, but he is not much known in NZ from these German publications, though a translation of his Neu-Seeland (1863) appeared in English in 1867 and there was a new translation of his NZ Novara scientific report (1864) by the NZ Survey geologist Charles Fleming in 1959. In Vienna, Basle and elsewhere in Europe there are repositories of Hochstetter's papers, illustrations and collections, which have been studied by $\mathrm{Dr}$ Nolden (a NZ resident whose first language is German). For the volume under review, most of the writing has been done by Johnston, formerly a geologist with the NZ Geological Survey and now active as an historian of geology and resident of Nelson. He knows the geology and topography of NZ intimately, and especially Nelson Province.

Like H. F. von Figure 1. Picture illustrating geothermal activity by the Waikato Haast's biography, this River, North Island. From Hochstetter's New Zealand (1867). The book gives much infor- terracing was done by Maori. A village or pa can be seen on the left mation about NZ social above the terraces. history, as well as topography, and also relations with the Maori. Unlike the biography, it is produced with high-quality paper making possible the reproduction in colour of many of the geologists' drawings and maps and their eventual published versions. There are also excellent maps showing the survey routes and numerous nineteenth-century photographs of localities where the survey parties visited as well as some beautiful watercolours by a resident NZ artist and amateur geologist, Charles Heaphy, with whom Hochstetter and Haast interacted. Hochstetter established a provisional stratigraphic arrangements of the rocks, without seeking to integrate the two islands in a combined system. He gave close attention to the famous volcanic and geothermal areas of the North Island (see for example Figure 1), identified deposits south of Auckland as being the product of air-borne volcanic ash, and noted the large iron-sand deposits of the western coast of the North Island as being of significant economic potential (only tapped relatively recently). $\mathrm{He}$ was appropriately cautious about both the coal and gold deposits, but the former at least is still prospering. On the other, hand he rejected the claim made by certain 'boosters' in Nelson about supposed rich copper deposits, though pointing out that there might be payable chromite deposits. But the local boosters were not deterred and a lot of money was wasted on unsuccessful mining ventures.

It is interesting to see (through photos and written accounts) the extent of the spread of European colonization into NZ by the 1860 s. Farming was going well adjacent to the colonial settlements and the Europeans were

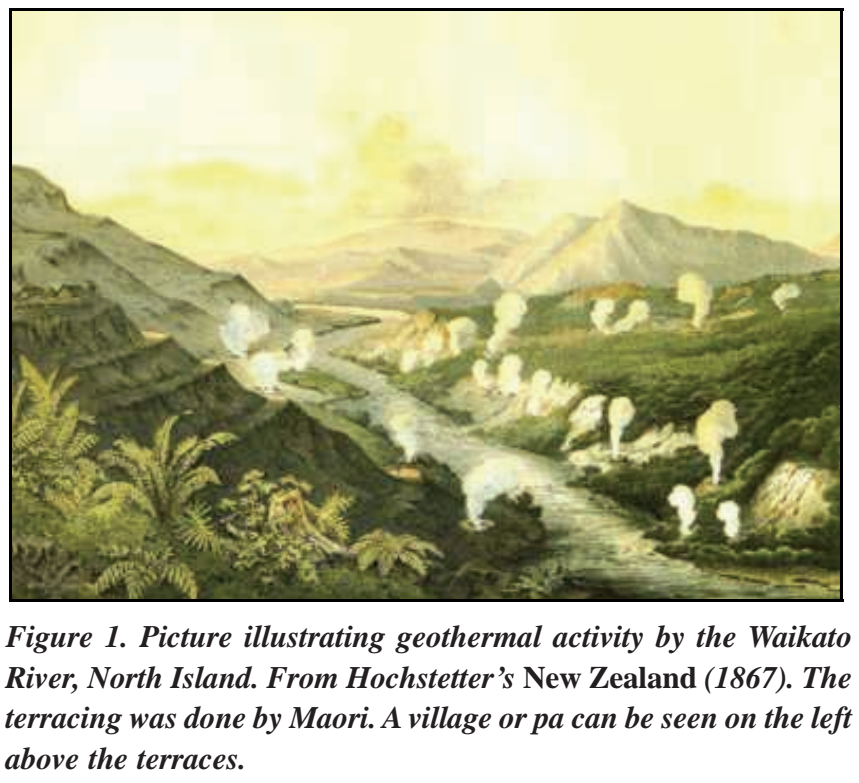


developing a moderately cultured civil society, with new buildings going up and societies being established for the benefit of the educated elite. As regards the sciences, geology was the first to become established on a professional basis. The country was still fairly peaceful before the Maori or New Zealand Wars became really serious, as the Maoris realised that their lands were being increasingly usurped by the settlers. (We are reminded in this book that much of the land on the west coast of the South Island was purchased for $£ 300$ !) Hochstetter seems to have picked up some Maori language and the expeditions received assistance from local indigenous people.

An appraisal of what Hochstetter and Haast accomplished is perhaps most easily gauged by considering the maps that they prepared, many of which are reproduced by Johnston and Nolden. The maps are admirably reproduced, the ones of the northern part of the South Island being perhaps the most impressive (given that mapping volcanic cones and lava flows round Auckland was by comparison a relatively simple task). Hochstetter was a superb cartographer, as can be seen, for example from the unpublished and published versions of his illustration of the volcanic cone of Mount Wellington near Auckland.

Even more impressive is the quality of Hochstetter's cartography in the published version of his geological map of Nelson Province (see Figure 2). Considering the short amount of time devoted to compiling this map, in difficult country, the result is quite remarkable. The offset of the band of the mineral belt (dark green) at the northeast flowing Wairau River is noteworthy as it gives a hint of the presence of one of the splays of the subsequently famous Alpine Fault.
Haast's field map (Figure 3) was, by comparison, rather crude. However, it should be said in this context that at the time Haast was a relatively inexperienced geologist, and (as Johnston and Nolden recount in detail) he did his work, without Hochstetter's guiding hand, in difficult and only partly explored country, and under adverse weather conditions. It will be noticed that his rock classification was much the same as that deployed by Hochstetter and was comparable to that used in Europe at the time. Incidentally, shortly after Haast's Nelson work he was invited to Christchurch to report on the railway tunnel then being excavated through the extinct volcano of Banks Peninsula to connect Christchurch with its port of Lyttelton. He produced a huge section of the walls of the tunnel, which for many years occupied the whole length of the main gallery of the museum in Christchurch. It was the first such profile ever to have been produced

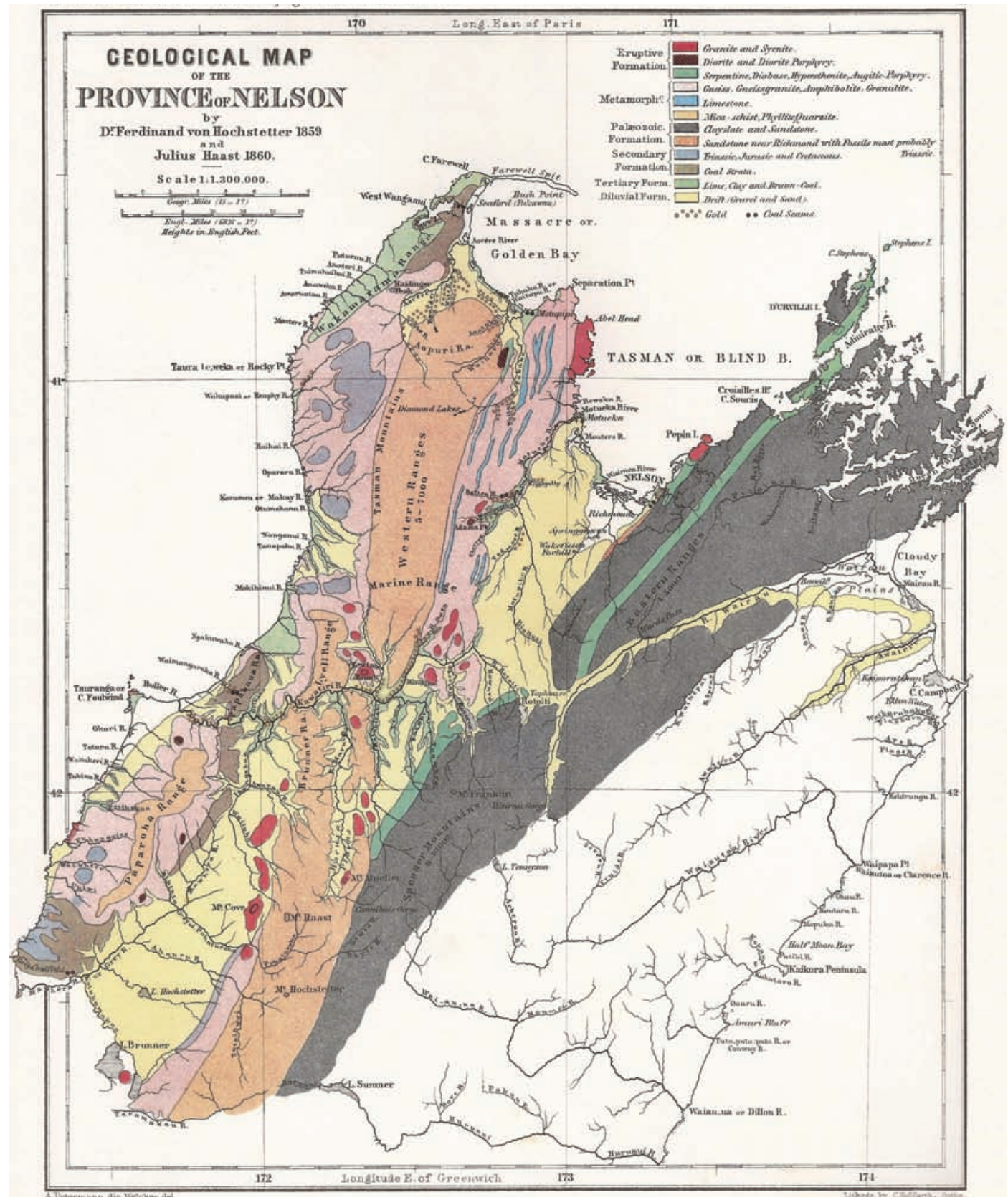

Figure 2. Published version of Hochstetter's Nelson map (1864). Red = granite and syenite; Purple = diorite and diorite porphyry; Dark green = serpentine, diabase, hypersthenite, augite-porphyry (mostly mineral belt); Pink = gneiss, gneiss-granite, amphibolite, granulite; Blue = limestone $;$ Orange = mica-schist, phyllites, quartzite; Grey = Palaeozoic clay-slate and sandstone; Orange = sandstones with fossils, possibly Triassic; Mauve = Triassic, Jurassic, Cretaceous; Light green = limestone, clay and brown coal (Tertiary); Yellow = diluvium. (Southwest portion of map based on information from Haast). 


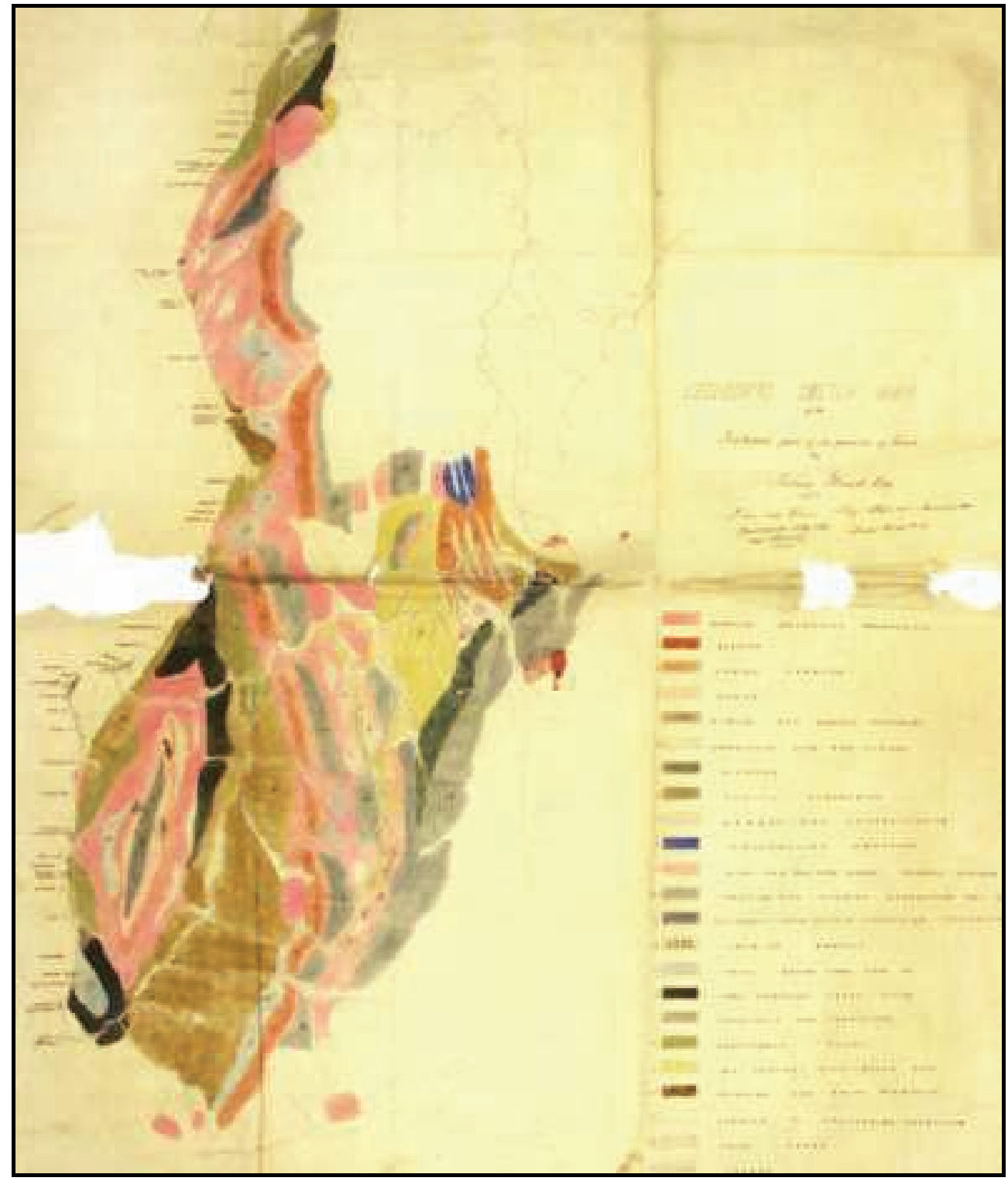

Figure 3. Haast's MS geological map of the western part of Nelson Province (1861). Units represented: Granite; Syenite; Gneiss Granite; Gneiss; Diorite; Hornblende rock and Schists; Diabase; Augitic Porphyry; Gabbro and Hypersthenite; Crystalline Limestone; Mica and old Clay Slates, Quartz, \&c.; Cambrian \& Silurian Sandstones; Metamorphic rocks without distinctive character; Granitic breccia; Trias below Clay Slates \&c.; Coal formation, Great Oolite; Cretaceous coal formation; Cretaceous rocks; Old Tertiary with brown coal; Pliocene and Drift formations; Lignite in preceeding [sic] formation; Drift dunes; Swamps; Recent alluvium. Reproduced by courtesy of Albert Schedl, Vienna.

and was a masterly accomplishment.

One matter for which Hochstetter is still widely remembered is his proposing the name 'dunite' for an unusual rock, composed of the mineral olivine, which he observed forming Dun Mountain in Nelson's mineral

mantle, dunite's presence is now regarded as a manifestation of obductive processes occurring in regions of plate tectonic activity, of which NZ is obviously one. Dunite is also commonly associated with chromite (but not copper).

Travels of Hochstetter and Haast is thoroughly researched and felicitously written and deals thoroughly with a topic that had long been demanding monograph attention! Readers from countries other than NZ will probably find trouble with the many Maori names (though Haast scattered names of famous European scientists on mountain tops like confetti). But with the admirably clear route maps provided, readers should have no difficulty in following Hochstetter and Haast around. And, as the book's title indicates, it is their travels that provide the thread to understanding what they saw, whom they met, what they did, and what they accomplished in NZ. However, it is unfortunate that the figures are un-numbered and hence are not linked to precise points in the text.

I should confess to having a special interest in this book, as back in 1967 I completed my MSc thesis for University College London on 'Geology in New Zealand Prior to 1900'. Today that appears as a primitive piece of work, kindly typed for me by my wife on a basic typewriter; and for the coloured maps that I reproduced, I had to handcolour separately using water-colour paint, each of the three copies of the thesis that I submitted. How times have changed with the advances in technology! But more than that, Johnston and Nolden have now done

belt. The olivine weathers to a rusty dun colour, gives rise to almost no soil, and has a chemical composition that is uncongenial to plants, so that the rounded top of the mountain is virtually devoid of vegetation. Thought to be derived from the Earth's the work that I should like to have done myself_-but never did. I am delighted with their accomplishment.

\section{David Oldroyd}

The University of New South Wales 